\title{
Menggali Potensi Kekayaan Motif Batik Modern Perkumpulan Batik Sido Luhur Pakualaman Yogyakarta
}

\section{Exploring the Potential Wealth of Modern Batik Motif Sido Luhur Pakualaman Batik Association Yogyakarta}

\author{
${ }^{1}$ Muafi, ${ }^{2}$ Muchammad Sugarindra, ${ }^{1 E n d a r ~ A b d i ~ P r a k o s o ~}$ \\ ${ }^{1}$ Jurusan Manajemen, Fakultas Bisnis dan Ekonomika, Universitas Islam Indonesia, \\ Yogyakarta \\ ${ }^{2}$ Jurusan Teknik Industri, Fakultas Teknik Industri, Universitas Islam Indonesia, \\ Yogyakarta
}

Korespondensi: muafi@uii.ac.id

Naskah Diterima: 26 Januari 2020. Disetujui: 20 Februari 2020. Disetujui Publikasi: 12 Juni 2020

\begin{abstract}
Sido Luhur Pakualaman Batik Association has a unique batik motif that is Mount Ketur motif. The Mount Ketur motif comes from historical values in the Pakualaman community. The historical value which is embodied in the batik motif is one of creativity forms from the craftsmen for their intellectual property. Each motif formed from each batik craftsman has extraordinary potential in terms of beauty, local wisdom, and meaning of life. Batik motifs become a very decisive element because from the motif, we will know whether batik has a "spirit" or not. This service activities has aim to explore and demonstrate the potential wealth of batik motifs owned by the Sido Luhur batik association so that it can be used as a medium for product quality improvement and product promotion media. The activity method consists of 3 steps: discussion, socialization, and intense mentoring. The results of community service activities have a positive impact on associations, such as increasing the member's creativity, number of modern motifs created, and ability to maintain product quality. Beside that, the community service activities also can compile product catalogs of all batik motifs and have a strong enthusiasm to obtain Intellectual Property Rights in the form Copyright of batik motifs.

Keywords: batik motifs, philosophy, utilization.
\end{abstract}

\begin{abstract}
Abstrak. Perkumpulan Batik Sido Luhur Pakualaman memiliki motif batik yang khas yaitu motif Gunung Ketur. Motif Gunung Ketur sendiri berasal dari nilai-nilai histori yang ada di masyarakat Pakualaman. Nilai histori yang diwujudkan dalam bentuk seni motif batik tersebut merupakan salah satu bentuk daya kreativitas pengrajin atas kekayaan intelektual yang dimilikinya, sehingga setiap motif yang terbentuk dari masing-masing pengarjin batik memiliki potensi yang luar biasa dari segi keindahan, kearifan lokal dan makna hidup. Motif batik menjadi unsur yang sangat menentukan karena dari motif itulah dapat diketahui apakah sebuah batik memiliki "roh" atau tidak. Kegiatan pengabdian ini memiliki tujuan untuk menggali dan menunjukkan potensi kekayaan motif batik yang dimiliki oleh perkumpulan batik Sido Luhur sehingga dapat dimanfaatkan sebagai media peningkatan kualitas produk dan media promosi produk. Metode kegiatan terdiri dari 3 langkah yaitu diskusi, sosialisasi dan pendampingan secara intens. Hasil kegiatan pengabdian memberikan dampak yang positif bagi perkumpulan, diantaranya meningkatkan daya kreatifitas anggota, menambah jumlah motif modern yang diciptakan, menambah kemampuan untuk menjaga kualitas produk, tersusunnya katalog produk dari semua motif batik yang dimiliki serta memiliki semangat yang kuat untuk
\end{abstract}


mendapatkan Hak Kekayaan Intelektual berupa Hak Cipta motif batik.

Kata Kunci: motif batik, filosofi, pemanfaatan.

\section{Pendahuluan}

Perkumpulan Batik Sido Luhur merupakan kelompok UKM Batik di Kecamatan Pakualaman Yogyakarta. Kelompok perajin batik tulis dengan ciri motif batik Gunung Ketur dimana melambangkan nama kampung Gunung Ketur yang merupakan warisan budaya yang ada di sekitar Kraton Puro Pakualaman. Motif Gunung Ketur terdiri dari lambang gunung dan bunga tanjung yang merupan tanaman yang ada disekitar Puro Pakualaman. Kelompok perajin ini terdiri dari 35 orang anggota yang semuanya ibu-ibu perajin batik. Mereka sepakat dengan merek dagang bersama untuk produk batiknya dengan nama Pendopo Kencono. Nama Pendopo Kencono diambil karena ibu-ibu perajin batik melakukan kegiatan batiknya di Pendopo Brotodiningrat. Perkumpulan ini didirikan sejak tahun 2017, namun kegiatannya belum terlalu aktif hingga akhirnya pada tahun 2019 perkumpulan Sido Luhur mendapatkan bantuan dari Disperindag DIY berupa fasilitasi merek kolektif, sejak bantuan dari Disperindag tersebut Perkumpulan Batik Sido Luhur mendapatkan banyak jaringan dan mengikuti banyak event-event batik yang dilaksanakan oleh dinas setempat maupun kementrian.

Popularitas batik saat ini mendorong pengrajin untuk terus berinovasi agar dapat menghadirkan batik yang indah dengan tujuan melestarikan budaya bangsa dengan tetap memperhatikan potensi local Indonesia (Martuti, Hidayah \& Margunani, 2019). Hasil dari proses membatik adalah terciptanya sebuah produk yang memiliki berbagai corak motif tertentu, setiap motif yang diciptakan oleh perajin memiliki arti dan makna tersendiri (Rahayu, 2011). Motif batik menjadi unsur yang sangat menentukan karena dari motif itulah kita dapat mengetahui apakah sebuah batik memiliki "roh" atau tidak. Motif batik juga menunjukkan dari mana suatu batik berasal. Di masyarakat, usaha batik biasanya dilakukan secara berkelompok dengan melibatkan banyak orang dengan berbagai keahlian mulai dari keahlian menggambar pola, mencanting, mencolet, proses pewarnaan, mencuci, hingga menjemur kain (Anshori \& Kusrianto, 2011).

Motif Gunung Ketur menjadi motif ciri khas Perkumpulan Sido Luhur, motifmotif lain juga terus dikembangkan oleh ibu-ibu perajin batik sehingga banyak tercipta berbagai macam motif batik yang menarik untuk digali potensinya seperti motif Gunung Ketur tersebut. Filosofi pembuatan motif batik memiliki berbagai macam latar belakang, ada yang dibuat berdasarkan suatu harapan, keindahan, atau lambang falsafah hidup masyarakat. Meskipun beragam, tidak menutup kemungkinan beberapa daerah memiliki motif batik yang sama namun bercorak dan bernilai berbeda. Pada dasarnya, kain batik tulis yang diciptakan dengan sepenuh hati memiliki jiwa yaitu jiwa yang menyukai kelembutan, kedamaian, dan toleransi (Arini \& Musman, 2011). Motif batik tradisional dikatakan sebagai kreasi seni dan masyarakat luas mengakuinya. Karya seni adalah suatu kreasi yang melibatkan cipta, rasa, dan karsa manusia, merupakan pengejawantahan dari ekspresi manusia yang menyangkut rasa, emosi, cita-cita, harapan, gagasan, khayalan, serta pengalamannya, yang divisualisasikan pada suatu media, dengan keterampilan dalam bentuk-bentuk berstruktur yang merupakan satu kesatuan yang organis, dengan menggunakan media indrawi, sehingga dapat ditangkap dan ditanggapi oleh indera manusia sebagai suatu yang bermakna bagi pencipta dan pengamatnya (Arini \& Musman, 2011).

Pada saat ini Perkumpulan Batik Sido Luhur sedang melalui aktifitas kegiatan membatik dengan sangat baik sehingga ada berbagai macam inovasi motif yang telah diciptakan, namun motif yang telah diciptakan tersebut tidak didokumentasi terlebih dahulu sehingga pada saat dibutuhkan lagi motif yang serupa seringkali 
motif yang diberikan agak berbeda. Tidak konsistennya motif batik ini menjadi permasalahan yang paling utama karena berkaitan dengan kualitas produk batik yang dijanjikan oleh konsumen dan berkaitan pula dengan bagaimana seharusnya mempromosikan kain batik tersebut. Oleh karena itu, maksud dari kegiatan pengabdian masyarakat ini adalah untuk menggali dan menunjukkan potensi kekayaan motif batik yang dimiliki oleh perkumpulan batik Sido Luhur sehingga dapat dimanfaatkan sebagai media peningkatan kualitas produk dan media promosi produk.

Kegiatan pengabdian ini dilakukan untuk mendukung Renstra Penelitian UII 2016-2020 yakni Peningkatan Kehidupan Masyarakat Madani dan Lestari (baldatun thoyibatun wa-robbun ghofur), yang selaras dengan cita-cita luhur para pendiri UII melalui Pengembangan Model Peningkatan Kualitas Hidup Islami. Kegiatan pengabdian ini menekankan pada rasa saling menghargai atas hasil kerja keras karya seseorang untuk memberikan nilai yang lebih tinggi atas apa yang telah dikerjakannya. Allah SWT berfirman QS At-Taubah ayat 105 "Bekerjalah kamu, maka Allah dan Rasul-Nya serta orang-orang mukmin akan melihat pekerjaanmu itu, dan kamu akan dikembalikan kepada (Allah) Yang Mengetahui akan yang gaib dan yang nyata, lalu diberitakan-Nya kepada kamu apa yang telah kamu kerjakan".

Kegiatan pengabdian masyarakat ini sejalan dengan hasil penelitian yang telah dilakukan sebelumnya. Muafi \& Uyun (i2018a) menemukan hasil bahwa pembelajaran organisasi mampu memediasi praktik SDM Islam terhadap kinerja non bisnis (sosial, lingkungan, religius). (Muafi, 2016; Muafi, Susilowati \& Suparyono, 2016) menemukan bahwa inkubasi bisnis dapat meningkatkan kinerja keuangan UMKM. (Muafi, 2016a) meneliti kinerja lingkungan dan sosial untuk UKM di Kota Yogya DIY. Hasilnya kinerja lingkungan dan sosial dipengaruhi oleh external fit (keseuaian dengan lingkungan eksternal) organisasi. (Muafi et al, 2016b) peran perempuan dalam meningkatkan kinerja kawasan berbasis Tanaman Krisan. Kinerja kawasan diukur dari kinerja ekonomi, sosial, dan lingkungan. Muafi \& Uyun (2018b) meneliti UKM di Kota Yogya dengan kesimpulan bahwa inovasi organisasi berperan penting dalam meningkatkan kinerja UKM. Muafi \& Sugarindra (2019) melakukan pengabdian yang berbasis merek yang digunakan secara bersama-sama di Desa Banyuripan Bayat. Hasil kegiatan membuktikan bahwa dengan menggunakan kekayaan motif yang dimiliki dapat memberikan nilai tambah produk yang dijual. Pada kegiatan pengabdian ini mempunyai tujuan untuk meningkatkan daya saing Perkumpulan Batik Sido Luhur, memberikan bimbingan teknis cara menggali potensi motif batik yang diciptakan dan untuk meningkatkan nilai tambah ekonomi serta produktivitas pembatik di Perkumpulan Batik Sido Luhur khususnya dan masyarakat Pakualaman umumnya. Dengan tercapainya tujuan kegiatan pengabdian maka akan memberikan manfaat kepada perkumpulan berupa peningkatan kualitas produk dan media promosi produk dengan cara mengadministrasikan setiap motif yang diciptakan, membuat dokumen pendukungnya (buku katalog), dan mengupas filosofi penciptaan pada setiap motif batik yang dimiliki.

\section{Metode Pelaksanaan}

Tempat dan Waktu. Kegiatan pengabdian pada masyarakat ini dilaksanakan di Jl. Suryopranoto, Gang Mangga PA III/364, Gunung Ketur, Pakualaman, Kota Yogyakarta. Kegiatan pengabdian dilaksanakan selama 3 bulan yaitu dimulai pada bulan November 2019 hingga Januari 2020.

Khalayak Sasaran. Sasaran dari kegiatan ini adalah Perkumpulan Batik Sido Luhur mempunyai kekuatan identitas pada setiap motif batik yang telah diciptakan sehingga dapat menambah kekuatan daya saing serta lebih konsisten dalam proses 
produksi. Adapun sasaran peserta pengabdian ini adalah anggota Perkumpulan Batik Sido Luhur Pakualaman Yogyakarta

Metode Pengabdian.Untuk mengatasi permasalahan yang dialami Perkumpulan Batik Sido Luhur, maka metode pelaksanaan kegiatan yang diajukan dalam pengabdian ini adalah sebagai berikut :

1. Diskusi

Kegiatan akan dilakukan dengan model diskusi dengan pembatik di Perkumpulan Batik Sido Luhur, khususnya yang terkait dengan kreasi motif batik yang ada di sekitar lingkungan Pakualaman. Diskusi dilakukan dengan tujuan untuk menyamakan persepsi dan gagasan dengan adanya kegiatan pengabdian masyarakat ini dan juga untuk mengidentifikasi proses produksi agar lebih memperhatikan filisofi yang terkandung pada saat proses produksi.

2. Sosialisasi

Memberi pemahaman yang lebih mendalam mengenai potensi dari masingmasing motif yang dimiliki oleh para anggota perkumpulan. Motif yang tercoret dalam sebuah kain tidak hanya sebagai nilai keindahan saja namun juga memiliki nilai histori dalam setiap penciptaannya yang dapat menambah nilai kain batik tersebut.

3. Pendampingan

Untuk memberikan pemahaman yang mendalam dan menuntun kepada teknis penggalian potensi motif batik maka diperlukan pendampingan yang berkesinambungan. Pendampingan dilakukan secara berkala mulai dari penampingan membuat motif, membatik, hingga pembuatan katalog produk.

Indikator Keberhasilan. Kegiatan pengabdian ini memiliki indikator keberhasilan yang sudah ditentukan sejak awal kegiatan dan sudah disepakati bersama-sama dengan mitra pengabdian. Indikator yang sudah ditentukan dapat terpenuhi secara baik dan memuaskan, indikator tersebut diantaranya :

1. Terselenggaranya kegiatan sosialisasi sesuai dengan jadwal yang ditentukan merupakan indikator keberhasilan dari kegiatan diskusi.

2. Jumlah kehadiran anggota perkumpulan pada saat sosialisasi yaitu di atas $70 \%$ dari jumlah total anggota pada saat kegiatan sosialisasi.

3. Meningkatkan daya kreatifitas anggota sehingga setiap anggota memiliki minimal 1 motif batik setelah adanya kegiatan sosialisasi.

4. Menambah jumlah motif modern yang diciptakan setelah adanya pendampingan.

5. Menambah kemampuan untuk menjaga kualitas produk setelah adanya pendampingan.

6. Tersusunnya katalog produk dari semua motif batik yang dimiliki setelah adanya pendampingan.

Metode Evaluasi. Metode evaluasi yang dilakukan oleh tim pengabdi yaitu dengan cara memberikan kuesioner evaluasi pelaksanaan kegiatan secara keseluruhan dari awal kegiatan pengabdian yang meliputi kegiatan diskusi, sosialisasi dan pendampingan yang sudah diisi oleh anggota Perkumpulan Batik Sido Luhur saat kegiatan sudah selesai dilakukan. Dari isian kuesioner tersebut dapat diperoleh timbal balik yang dapat digunakan sebagai bahan evaluasi dan peningkatan kualitas pengabdian bagi tim pengabdi.

\section{A. Diskusi}

\section{Hasil dan Pembahasan}

Pertama, yaitu melakukan kegiatan dengan model diskusi dengan pembatik di Perkumpulan Batik Sido Luhur Pakualaman, diskusi ini dilakukan dengan tujuan untuk menyamakan persepsi dan gagasan dengan adanya kegiatan pengabdian masyarakat ini dan juga untuk mengidentifikasi proses produksi agar lebih memperhatikan filisofi yang terkandung pada saat proses produksi. Diskusi 
dilakukan bersama tim pengabdi dan pengurus harian perkumpulan batik (Gambar 1). Dari kegiatan yang pertama ini, para pengurus perkumpulan batik sangat antusias untuk mengikuti program yang telah dipaparkan, yaitu menggali potensi kekayaan motif batik. Hasil diskusi ini akan ditindaklanjuti dan menjadi dasar untuk kegiatan yang selanjutnya yaitu sosialisasi. Dari hasil diskusi ini diperoleh keadaan perkumpulan batik yang lebih mendalam sehingga tim pengabdi dapat lebih memberikan stimulus yang lebih baik pada saat sosialisasi agar tujuan dari kegiatan ini dapat tercapai.

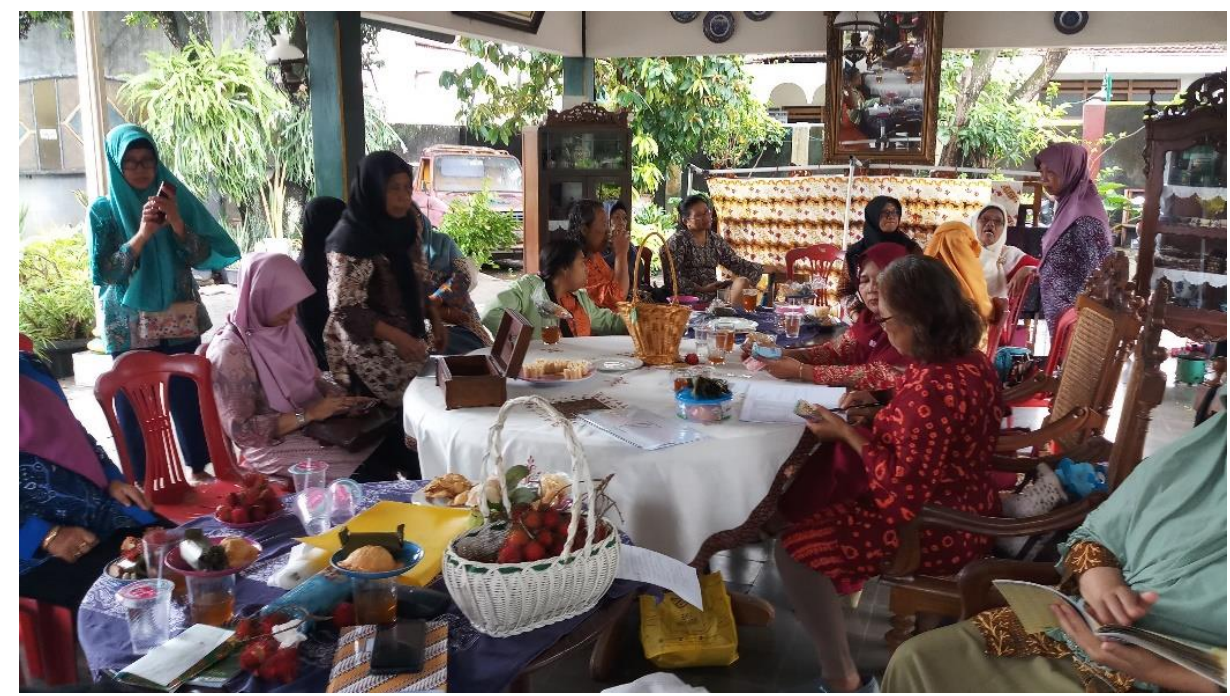

Gambar 1. Diskusi dengan Pengurus Harian Perkumpulan

\section{B. Sosialisasi}

Pada tahapan kegiatan yang kedua, yaitu sosialisasi potensi kekayaan motif batik dengan tujuan memberi pemahaman yang lebih mendalam mengenai potensi dari masing-masing motif yang dimiliki oleh para anggota perkumpulan (Gambar 2). Kegiatan sosialisasi diadakan pada hari Jum'at 13 Desember 2019 bertempat di pendopo Brotodiningrat Jl. Suryopranoto, Gang Mangga PA III/364 RT. 14 RW. 04, Gunungketur, Pakualaman dengan dihadiri oleh 25 anggota perajin batik. Total anggota terdaftar yaitu 35 anggota sehingga prosentase kehadiran anggota perkumpulan dari kegiatan sosialisasi yaitu lebih dari 70\%. Kegiatan diikuti dengan suasana yang kondusif dan penuh semangat, respon positif selalu diberikan oleh ibu-ibu anggota perajin batik dengan memberikan beberapa tanggapan mengenai materi yang disampaikan dan memberikan beberapa pertanyaan terkait motif batik. Beberapa pertanyaan yang diberikan oleh ibu-ibu dominan mengenai tentang filosofi motif batik berkaitan dengan latar belakang penciptaan dan alur cerita filosofi motif batik tersebut. Kegiatan sosialisai ini memberikan beberapa kesepakatan diantaranya setiap anggota dianjurkan untuk memiliki motif sendiri yang merupakan hasil dari pemikirannya sendiri, setiap anggota dianjurkan untuk membuat 1-3 motif batik yang dapat dikombinasikan dengan berbagai motif batik tradisional, menjaga konsistensi kualitas produksi batik, setiap motif batik yang diciptakan oleh anggota akan dimasukkan ke dalam katalog produk, anggota akan diberikan fasilitas pendaftaran Hak Cipta motif batik bagi pemilik motif batik yang paling kreatif dan proses kegiatan pendampingan akan dampingi oleh Pihak Balai Batik Yogyakarta.

\section{Pendampingan}

Kegiatan yang ketiga, yaitu pendampingan yang dilakukan secara intens. Proses pendampingan dilakukan selama 5 minggu secara berturut-turut dari bulan Desember 2019 hingga Januari 2020. Kegiatan pendampingan bekerjasama dengan 


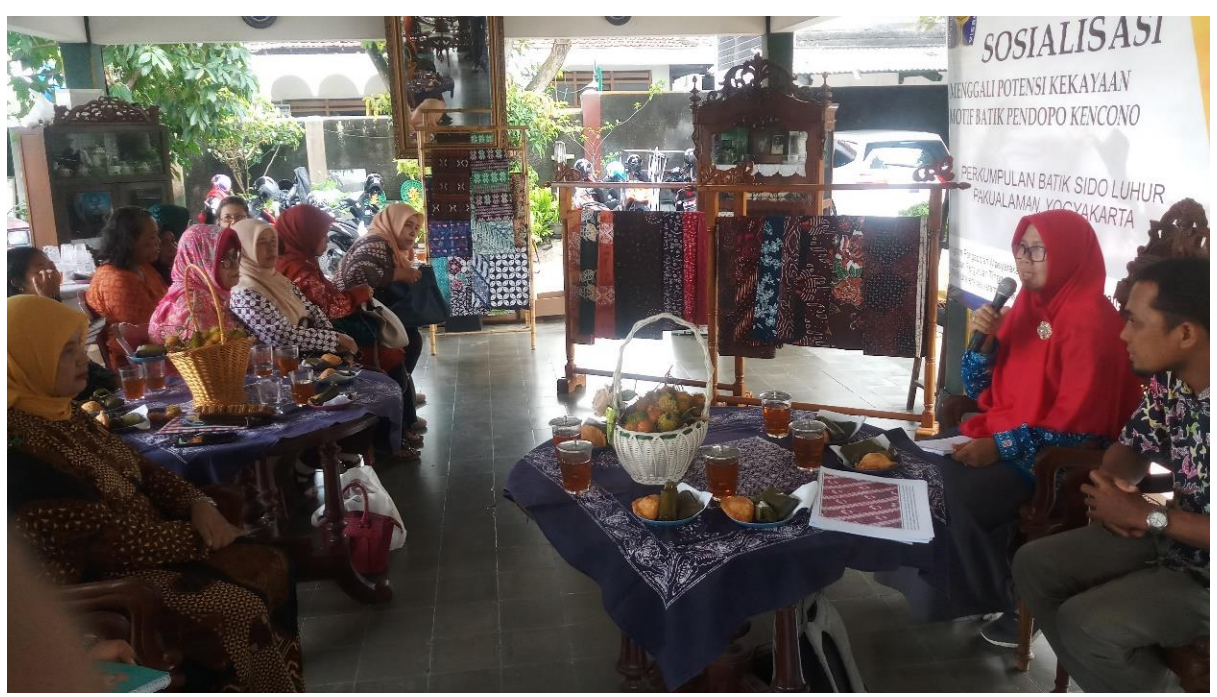

Gambar 2. Sosialisasi

pihak Balai Batik Yogyakarta dengan mendatangkan trainer batik untuk memberikan pembelajaran mengenai pembuatan motif batik modern (Gambar 2-5). Dari hasil kegiatan pendampingan ini, anggota telah memiliki minimal satu motif batik andalan yang sangat kreatif dan berasal dari hasil pemikiran mereka sendiri. Selain kegiatan pendampingan berupa pelatihan membatik, kegiatan pendampingan juga dilakukan dengan cara wawancara satu persatu anggota untuk menggali informasi dalam penyusunan filosofi penciptaan motif tersebut. Wawancara dilakukan secara intens dan mendalam dengan tujuan agar filosofi penciptaan yang dimaksudkan oleh pencipta motif batik dapat disusun dengan kalimat yang baik sehingga pesan yang terkandung dalam motif tersebut dapat tersampaikan oleh konsumen. Filosofi yang sudah tersusun memberikan makna tertentu pada kain batik tersebut sehingga dengan adanya filosofi yang bermakna, dapat menambah nilai jual kain batik tersebut. Pendampingan juga dilakukan guna menyusun katalog produk agar mempermudah proses pemasaran produk pada saat mengikuti event pameran, hal tersebut diakui juga oleh perkumpulan bahwa dengan adanya katalog produk sangat membantu proses pemasaran kepada konsumen.

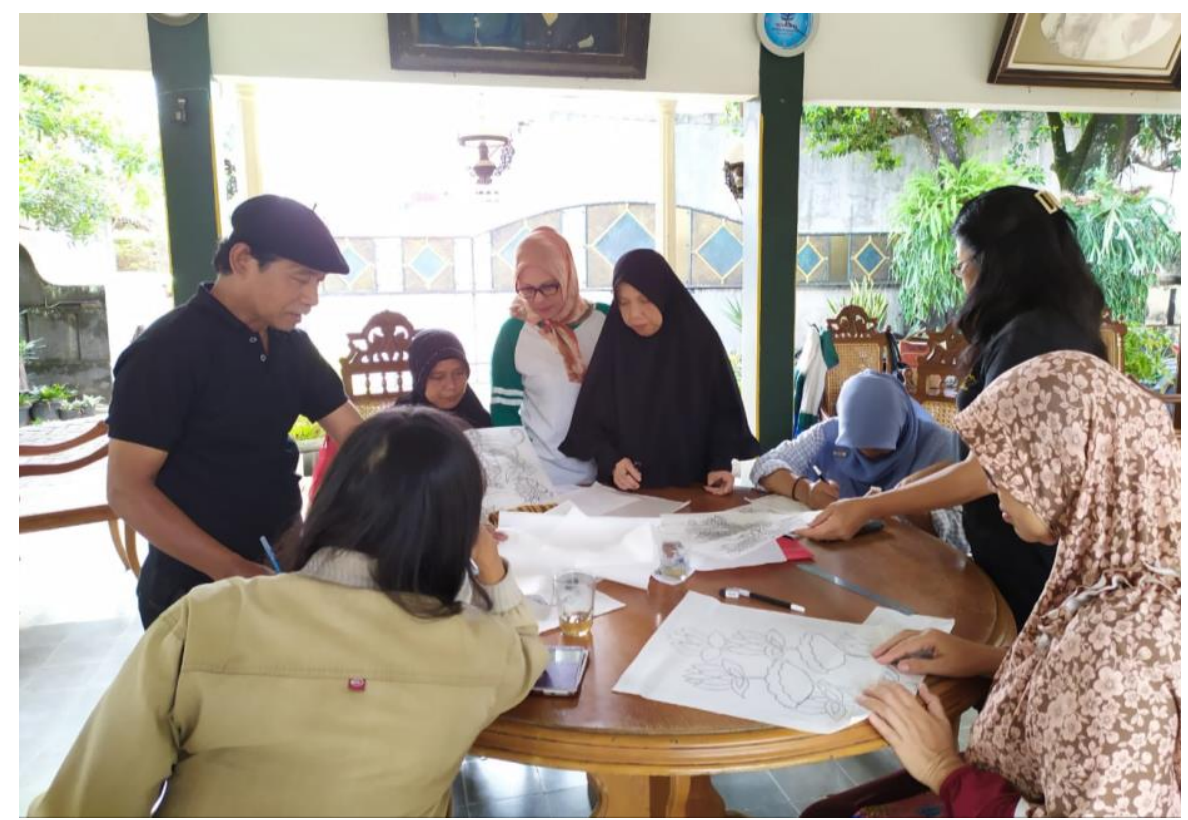

Gambar 3. Nyorek motif batik

Jurnal Panrita Abdi, 2020, Volume 4, Issue 2. 


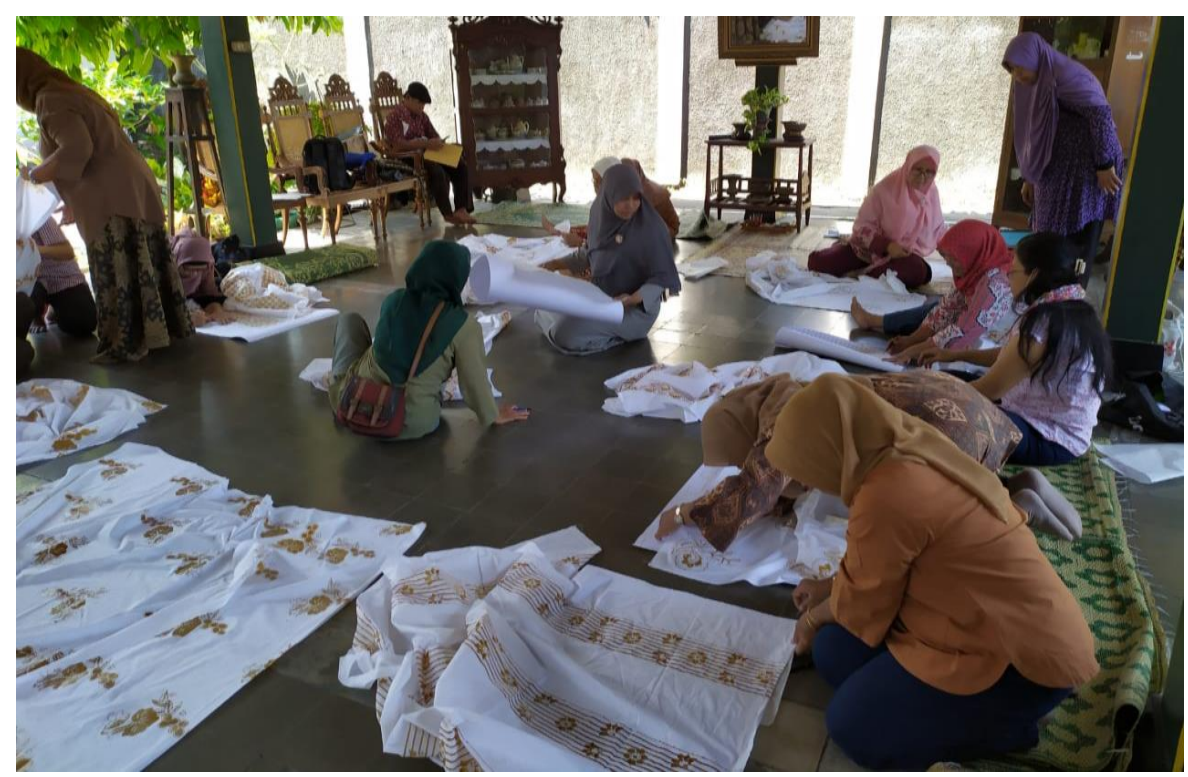

Gambar 4. Membatik motif modern

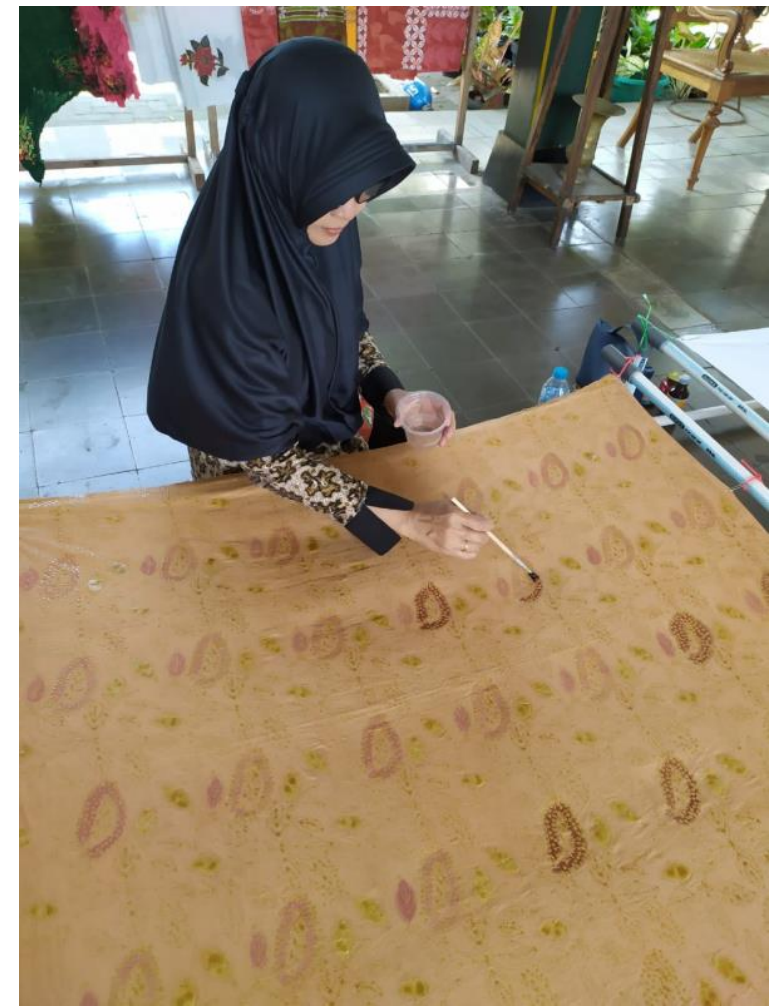

Gambar 5. Kreasi pewarnaan

Kegiatan pendampingan juga telah menghasilkan luaran berupa publikasi media massa berupa press release yang terbit di Harian Jogja dan Kedaulatan Rakyat. Dari hasil publiaksi media massa ini bertujuan untuk lebih mengenalkan Perkumpulan Batik Sido Luhur Pakualaman beserta motif yang dimilikinya kepada masyarakat, khususnya Yogyakarta. Berita terbit pada tanggal 13 Desember 2019 di koran online Harian Jogja dengan link url (https://jogjapolitan.harianjogja.com/read/2019/12/13/510/1027004/paguyu ban-ibu-ibu-kembangkan-motif-batik-khas-gunungketur) (Gambar 6). Sedangkan berita yang terbit di Koran Kedaulatan Rakyat pada tanggal 26 Desember 2019 (Gambar 7)lebih fokus kepada motif batik yang dimiliki oleh perkumpulan. 


\section{Paguyuban Ibu-Ibu Kembangkan Motif Batik Khas Gunungketur}

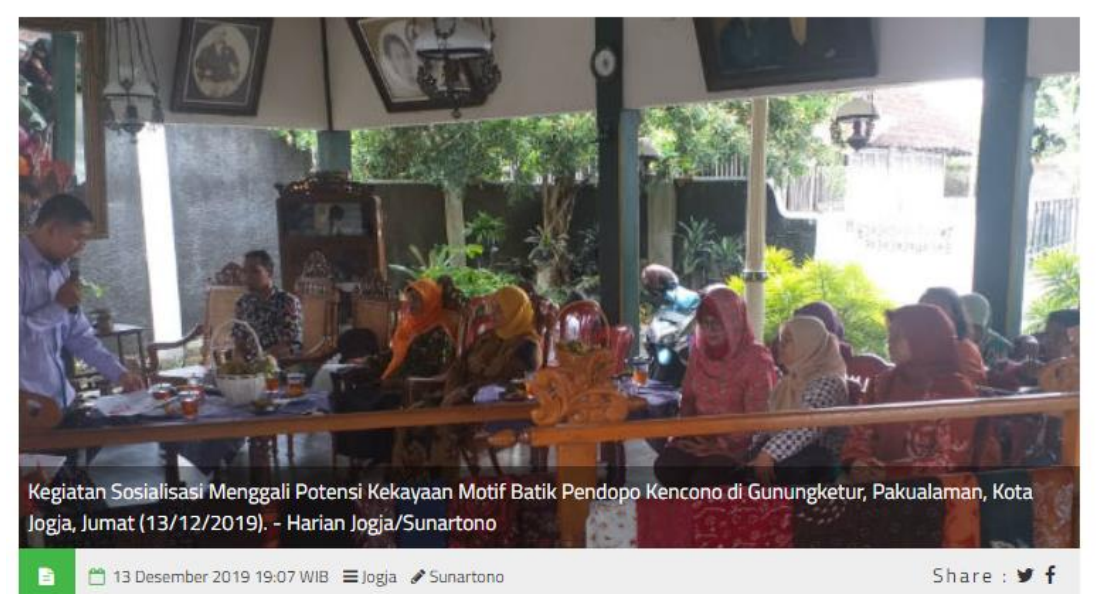

Gambar 6. Publikasi Harian Jogja

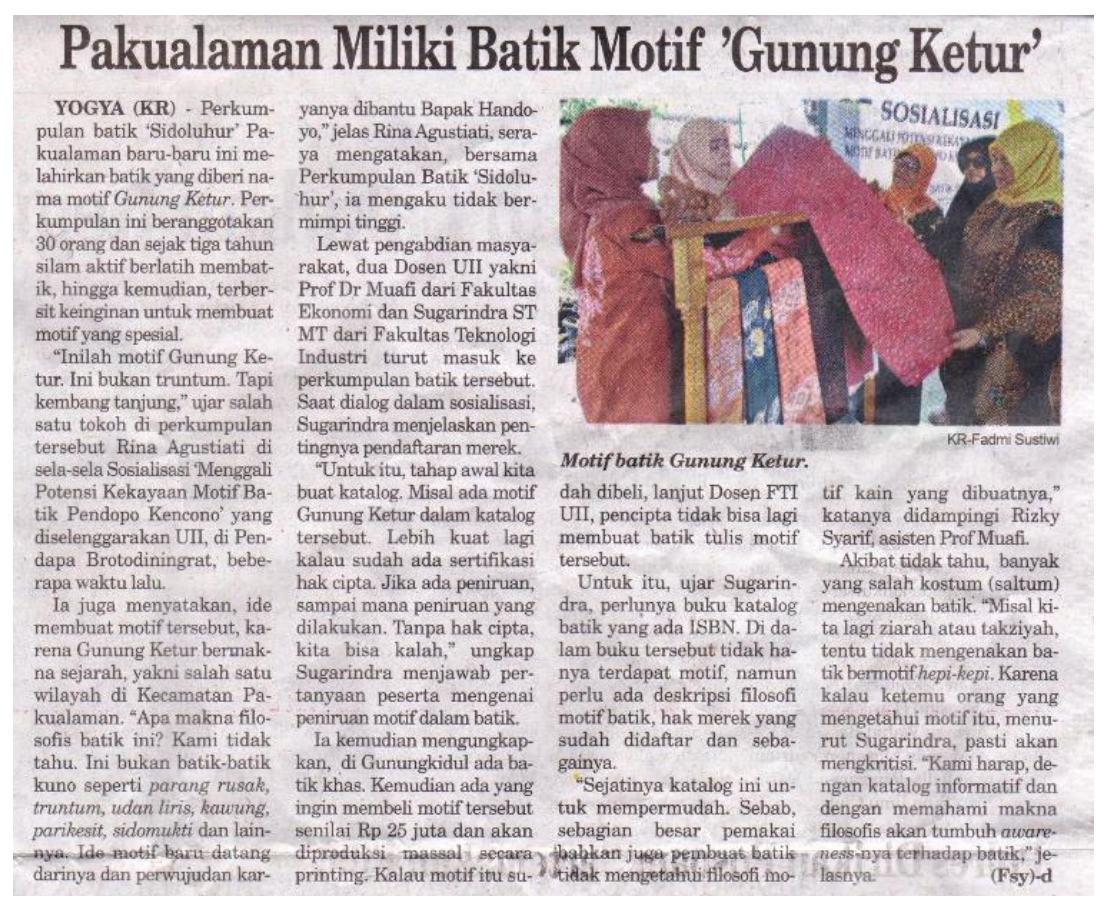

Gambar 7. Publikasi Koran Kedaulatan Rakyat

\section{Keberhasilan Kegiatan}

Keberhasilan kegiatan pengabdian masyakarat secara garis besar mencakup beberapa indikator keberhasilan sebagai berikut, yaitu 1) Jumlah kehadiran anggota perkumpulan pada saat sosialisasi yaitu diatas $70 \%$ dari jumlah total anggota, 2) meningkatkan daya kreatifitas anggota, 3) bertambahnya jumlah motif modern yang diciptakan, 4) bertambahnya kemampuan untuk menjaga kualitas produk, 5) tersusunnya katalog produk dari semua motif batik yang dimiliki, 6) memiliki semangat yang kuat untuk mendapatkan Hak Kekayaan Intelektual berupa Hak Cipta motif batik. Perkumpulan Batik Sido Luhur Pakualaman memiliki jumlah anggota 35 perajin, kehadiran pada saat kegiatan sosialisasi yaitu sebanyak 25 perajin sehingga prosentase kehadirannya yaitu $71,4 \%$, oleh karena itu indikator pertama telah tercapai dengan baik. Pada indikator kedua, para perajin kini telah memiliki 1-3 motif buatan sendiri sehingga daya kreatifitas anggota perkumpulan sudah meningkat karena pada awalnya hampir semua 
anggota belum memiliki motif, mereka membatik motif yang sudah ditentukan oleh ketua perkumpulan. Dengan terpenuhinya indikator kedua ini maka pada indikator ketiga pun telah tercapai karena jumlah motif yang dimiliki kini semakin variatif dan kreatif. Motif yang terinspirasi mulai dari tanaman, bunga, bangunan, peristiwa, hewan, hingga kenangan yang sangat membekas oleh perajin. Hingga saat ini, kesadaran perajin untuk terus menjaga kualitas produk telah meningkat. Membatik tidak hanya sekedar mencoret sebuah gambar motif namun juga dapat menjadikan sebagai media bercerita dan berkreasi. Luaran akhir dari program pengabdian ini adalah katalog produk berupa buku yang dibagikan kepada setiap anggota perkumpulan dan pendaftaran Hak Cipta motif perkumpulan, dengan adanya katalog produk diharapkan perkumpulan dapat melakukan proses pemasaran yang semakin efektif dan menarik. Adanya sertifikat Hak Cipta motif memberikan semangat bagi para perajin untuk terus berkreasi karena apa yang mereka ciptakan terasa berharga dan dihargai oleh orang lain. Oleh karena itu, dalam membatik tidaklah sekedar mencoretkan lilin pada kain namun juga menciptakan filosofi bermakna yang memiliki nilai histori ataupun harapan, dengan demikian pemanfaatan filosofi sebagai penambah nilai jual kain batik sangatlah efektif untuk diimplementasikan.

\section{Kesimpulan}

Keseluruhan kegiatan pengabdian dapat memperbaiki proses kegiatan produksi dan menambah daya kreatifitas para perajin untuk terus menciptakan motif-motif yang baru, memberikan wawasan dan ilmu kepada perajin Perkumpulan Batik Sido Luhur Pakualaman akan pentingnya filosofi dalam menciptakan sebuah motif batik, menambah motivasi perajin untuk terus berkarya dan menjual kain batik karena sudah ada katalog yang menarik untuk digunakan sebagai media penjualan.

\section{Ucapan Terima Kasih}

Tim Pengabdi mengucapkan terima kasih kepada seluruh pihak yang telah membantu kegiatan pegabdian ini. Ucapan terima kasih kami sampaikan khusus kepada DPPM Universitas Islam Indonesia Yogyakarta yang telah mendukung sepenuhnya secara materiil kegiatan pengabdian ini.

\section{Referensi}

Anshori, Y., \& Kusrianto, A. (2011). Keeksotisan batik jawa timur. PT. Elek Media Komputindo-2011-ISBN: 978-602-00-1195-0.

Arini, A. B., \& Musman, A. (2011). Batik: Warisan Adiluhung Nusantara. Yogyakarta: G-media.

Martuti, N. K., Hidayah, I., \& Margunani, M. (2019). Pemanfaatan Indigo Sebagai Pewarna Alami Ramah Lingkungan Bagi Pengrajin Batik ZIE. Jurnal Panrita Abdi, 3(2), 133-143.

Muafi, M. (2016). The Role of Robust Business Model in Ensuring External Fit and Its Impact on firms in social performance. Актуальні проблеми економіки (Rusia) Jurnal Masalah Ekonomi Aktual, (4), 257-264.

Muafi, \& Sugarindra, M. (2019). Identification And Technical Guidance Of Work Health And Safety Handling Of Batik Artisans At "Kebon Indah", Bayat, Klaten, Central Java, Indonesia. Asian Journal of Management Sciences \& Education Vol. 8, Number 2, April 2019

Muafi, \& Uyun, Q. (2018a). The Influence of Islamic HRM Practices on Organizational Learning and Its Impact on Environmental, Social And Religious Performance, Journal of Entrepreneurship Education, Vol. 21, Issue 3, p. $1-9$. 
Muafi, \& Uyun, Q. (2018b). The Role of Leadership Agility toward Organizational Learning and Imitation Behavior; a Study of the Manager of Batik SMEs in Pekalongan Indonesia, Proceedings of the 31st International Business Information Management Association Conference (IBIMA), 25-26 April, Milan, Italy p. 1122-1129.

Muafi, Roostika, R., Wijayani, A \& Poerwanto, M.E. (2016b). Strategic Role of Women in Chrysanthemum-Based Engineering Design on Disaster Affected Areas, IJBS - International Journal of Business and Society, Vol.8. No.3, p. 417-428.

Muafi,Susilowati, \& Suparyono (2016a). Competitiveness Improvement Of Green Area: The Case of OVOP in Bantul Region, Daerah Istimewa Yogyakarta (DIY), Province, Indonesia, International Business Management, 10(1), p. 24-31.

Rahayu, D. (2011). Perlindungan Hukum Terhadap Hak Cipta Motif Batik Tanjungbumi Madura. Mimbar Hukum-Fakultas Hukum Universitas Gadjah Mada, 23(1), 115-131.

Penulis:

Muafi, Jurusan Manajemen, Fakultas Bisnis dan Ekonomika, Universitas Islam Indonesia, Yogyakarta. E-mail: muafi@uii.ac.id

Muchammad Sugarindra, Jurusan Teknik Industri, Fakultas Teknik Industri, Universitas Islam Indonesia, Yogyakarta. E-mail : sugarindra@uii.ac.id

Endar Abdi Prakoso, Jurusan Manajemen, Fakultas Bisnis dan Ekonomika, Universitas Islam Indonesia, Yogyakarta. E-mail: 17311431@students.uii.ac.id

Bagaimana men-sitasi artikel ini:

Muafi, Sugarinda, M., \& Prakoso, E.A. (2020). Menggali Potensi Kekayaan Motif Batik Modern Perkumpulan Batik Sido Luhur Pakualaman Yogyakarta. Jurnal Panrita Abdi, 4(2), 245 - 254. 